\title{
PENGARUH PROFITABILITAS DAN BEBAN PAJAK TANGGUHAN TERHADAP MANAJEMEN LABA
}

\author{
Fibria Anggraini Puji Lestari
}

\author{
Program Studi Informatika, FTIK \\ Universitas Indraprasta PGRI \\ Email: fibria981@gmail.com
}

Diterima: November 2018; Disetujui: Nopember 2018; dipublikasikan: Desember 2018

\begin{abstract}
ABSTRAK
Penelitian ini untuk mengetahui pengaruh profitabilitas dan beban pajak tangguhan terhadap manajemen laba. Dalam penelitian ini data diperoleh dari 10 perusahaan minyak bumi di Indonesia yang terdaftar di BEI Jakarta. Penelitian ini menggunakan analisis liniear berganda dengan software SPSS 19.0 for windows. Hasil penelitian ini menunjukkan bahwa variabel profitabilitas $(0,151)$ dan beban pajak tangguhan $(0,629)$, berpengaruh positif terhadap manajemen laba yang dilakukan perusahaan.
\end{abstract}

Kata Kunci : Profitabilitas, beban pajak tangguhan, dan manajemen laba

\begin{abstract}
This research aimed to know the effect of deferred tax burden and profitability to earn management. In this research, data obtained from 10 petroleum companies in Indonesia that listed in BEI Jakarta. This research used double linear analysis with software SPPS 19.00 for windows. The result of this research showed that variable of profitability (0.151) and deferred tax burden $(0,629)$, positive toward the profit management of the company.
\end{abstract}

Keywords: Profitability, deferred tax expenseand earnings management

\section{PENDAHULUAN}

Dalam dunia usaha dimana Laporan keuangan merupakan media komunikasi yang menghubungkan antara pihak-pihak yang berkepentingan terhadap perusahaan. Dalam kaitannya sebagai media komunikasi, terdapat dua hal yang penting di dalamnya yaitu konsep pertanggungjawaban (stewardship) dan pengambilan keputusan (decision making). Menurut Wild, Subramanyam dan Halsey (2013) dalam konsep manajemen pertanggungjawaban, manajemen merupakan penanggung jawab atas penjagaan aset, peningkatan kekayaan ekuitas investor, dan perlindungan terhadap kreditor. Konsep pertanggungjawaban memberikan informasi mengenai kinerja manajemen perusahaan yang mempunyai implikasi pada proses pengambilan keputusan yang dilakukan oleh pihak eksternal sebagai pengguna laporan keuangan. Salah satu peran penting laporan keuangan digunakan untuk mengukur kinerja manajemen dan sebagai bahan pertimbangan dalam pengambilan keputusan pihak eksternal dalam hal ini laba (profitabilitas). Pengertian Profitabilitas adalah kemampuan perusahaan 
dalam memperoleh laba yang pengukurannya dihubungkan dengan volume penjualan, total aktiva maupun modal sendiri (Lukman, 2013 : 38). Tinggi rendahnya laba digunakan sebagai alat ukur dalam hal kenaikan aktiva tergantung pada ketepatan pengukuran pendapatan dan biaya. Prihat Assih dan Muhammad Gudono (2012:25) menyatakan perusahaan yang mempunyai ROA yang lebih tinggi akan berpotensi untuk melakukan manajemen laba karena manajemen mengetahui kemampuan perusahaan untuk mendapatkan laba pada masa mendatang sehingga dapat memudahkan dalam menunda atau mempercepat laba pada periode tertentu. Hal ini didukung dalam penelitian yang telah dilakukan oleh Igan Budiasih (2012 : 27) bahwa profitabilitas mempunyai pengaruh yang signifikan terhadap praktik perataan laba yang merupakan bagian dari praktik manajemen laba di perusahaan.

Berdasarkan latar belakang tersebut, selanjutnya penulis melakukan penelitian mengenai pengaruh beban pajak tangguhan dan profitabilitas terhadap manajemen laba yang dilakukan oleh perusahaan-perusahaan minyak bumi yang terdaftar di BEI.

Scott (2012:24) mendefinisikan manajemen laba sebagai "the choice by a manager of accounting policies so as to achieve some specific objective" yang kurang lebih memiliki arti : "pemilihan yang dilakukan oleh manajer dalam pengambilan keputusan guna mencapai tujuan perusahaan pada periode tertentu"

Menurut Magnan dan Comier,ada tiga sasaran yang ingin dicapai oleh manajer sehubungan dengan praktik earnings management (Gumanti, 2011 :19). Ketiga sasaran tersebut adalah:

a. Meminimalkan biayapolitis (political cost motivation)

b. Memaksimalkan kesejahteraan manajer (manager wealth maximization)

c. Meminimalkan biaya finansial (minimization of financialcosts)

Sasaran dari manajemen laba adalah cukup komprehensif,yaitu mencakup banyak aspek dalam perusahaan baik demi keuntungan pribadi manajer maupun perusahaan secara keseluruhan.

Profitabilitas adalah kemampuan perusahaan untuk memperoleh laba dengan masingmasing pengukuran yang dihubungkan dengan volume penjualan, total aktiva maupun modal sendiri (Lukman, 2013:22). Profitabilitas merupakan salah satu rasio keuangan yang menunjukan hasil akhir bersih dari berbagai kebijakan dan keputusan. Susan Irawati (2012:31) berpendapat bahwa profitabilitas merupakan rasio yang digunakan untuk mengukur efisiensi penggunaan aktiva perusahaan atau sebagai pengukur kemampuan perusahaan untuk menghasilkan laba selama periode tertentu. Sedangkan menurut pendapat Kashmir (2011:23) profitabilitas adalah rasio yang digunakan untuk menilai kemampuan perusahaan dalam mencari keuntungan dan sebagai pengukur tingkat efektivitas manajemen suatu perusahaan.

Dalam rasio profitabilitas ada beberapa rumusan yang digunakan antara lain adalah margin laba kotor (gross profit margin), margin laba operasi (operating profit margin), margin laba bersih (net profit margin), total assets turnover, rasio laba terhadap investasi (return on investment (ROI)), rasio laba terhadap asset (return on assets (ROA)), rasio laba terhadap ekuitas (return on equity $(R O E)$ ), return on common stock, laba per saham (earning per share), dividen per saham (deviden per share), nilai buku per saham (book value per share) (Lukman, 2013 : 32). Penelitian ini dikhususkan hanya pada ukuran profitabilitas perusahaan dengan proxy return on assets (ROA) karena ROA mampu merefleksikan keuntungan bisnis dan mewakili efektifitas perusahaan yang mencerminkan kinerja manajemen dalam pemanfaatan total asset untuk menghasilkan laba yang diinginkan oleh perusahaan. Rasio ini juga dapat mewujudkan hubungan investasi baru yang ditunjukkan pada arus kas bersih dikaitkan dengan total asset perusahaan.

Menurut Susan Irawati (2012 : 27) return on assets (ROA) adalah kemampuan suatu perusahaan (asset perusahaan) dengan seluruh modal yang bekerja di dalamnya untuk menghasilkan laba operasi perusahaan atau perbandingan laba usaha dengan modal sendiri dan 


\section{Sosio e-kons}

Volume 10, No. 3, Desember 2018, pp. 270-278

e-ISSN: 2502-5449

p-ISSN: 2085-2266

http://journal.lppmunindra.ac.id/index.php/sosio_ekons

modal asing yang digunakan untuk menghasilkan laba dan dinyatakan dalam persentase. Rumus yang digunakan adalah :

$$
\text { ROA }=\frac{\text { Earning After Tax (EAT) }}{\text { Total Assets }} \times 100 \%
$$

Keterangan :

- Earning After Tax = Pendapatan Setelah Pajak (laba bersih)

- Total Assets = jumlah Aset/Harta. (Sumber: Susan Irawati, 2012)

Pajak tangguhan adalah jumlah jumlah $\mathrm{PPh}$ yang terutang untuk peiode mendatang (payable) sebagai akibat dari adanya perbedaan sementara yang menimbulkan suatu jumlah kena pajak (future taxable amount) dalam perhitungan laba rugi fiscal periode mendatang pada saat nilai tercatat asset dipulihkan atau nilai tercatat liabilitas dlunasi.Pajak tangguhan dapat dibedakan menjadi Akiva Pajak Tangguhan (deferred taxassets) dan Kewajiban Pajak Tangguhan (deferred tax liabilities).

Dengan berlakunya PSAK No. 46 timbul kewajiban bagi perusahaan untuk menghitung dan mengakui pajak tangguhan (deferred taxes) atas future tax effects (efek pajak masa depan) dengan menggunakan pendekatan the assets and liability method (Metode Aset dan Kewajiban), yang berbeda dengan pendekatan income statement liability method (Metode Kewajiban Laporan Laba Rugi) yang sebelumnya lazim digunakan oleh perusahaan dalam menghitung pajak tangguhan (Moh. Zain, 2013:15). Pajak tangguhan dapat dibedakan menjadi Aktiva Pajak Tangguhan (deferred tax assets) dan Kewajiban Pajak Tangguhan (deferred tax liabilities). Di sisi lain, terdapat kewajiban pajak tangguhan yang merupakan jumlah pajak penghasilan terutang (payable) untuk tahun mendatang sebagai akibat adanya perbedaan temporer kena pajak.

Menurut Moh. Zain (2013 :23) baik Kewajiban Pajak Tangguhan maupun Aset Pajak Tangguhan dapat terjadi dalam hal-hal sebagi berikut :

a. Penghasilan yang sebelum pajak-PSP (Pretas Accounting Income) lebih besar dari penghasilan kena pajak-PKP (Taxable Income), maka beban pajak-BP (tax Expense) pun lebih besar dari pajak terutang-PT (Deferred Taxes Liability). Kewajiban pajak tangguhan dapat dihitung dengan mengalikan perbedaan temporer dengan tariff pajak yang berlaku.

b. Penghasilan yang sebelum pajak (PSP) lebih kecil dari penghasilan kena pajak (PKP), maka beban pajak (BP) juga lebih kecil dari pajak terutang (PT), hal ini akan menghasilkan Aktiva Pajak Tangguhan (Deferred Tax Assets). Aktiva pajak tangguhan adalah sama dengan perbedaan temporer dengan tariff pajak pada saat perbedaan tersebut terpulihkan.

\section{METODE}

Dalam penelitian ini menggunakan metode korelasional, yaitu metode yang digunakan untuk menentukan hubungan sebab akibat yang definitif dalam mencari pengaruh yang terjadi antara variabel-variabel bebas dengan variabel terikat (Sekaran, 2014:15).Penelitian ini melibatkan tiga komponen yaitu satu variabel terikat (dependen) dan dua variabel bebas (independen). Variabel terikatnya adalah manajemen laba( $\mathrm{Y}$ ) sedangkan variabel bebas yang terdiri dari: beban pajak tangguhan $\left(\mathrm{X}_{1}\right)$ dan profitabilitas $\left(\mathrm{X}_{2}\right)$. 


\section{Sosio e-kons}

Volume 10, No. 3, Desember 2018, pp. 270-278

e-ISSN: 2502-5449

p-ISSN: 2085-2266

http://journal.lppmunindra.ac.id/index.php/sosio_ekons

DOI: http://dx.doi.org/10.30998/sosioekons.v10i3.2895

\section{Tabel 1. Klasifikasi Variabel dan Indikator}

\begin{tabular}{|c|c|c|c|}
\hline Variabel & Definisi Operasional & Formula Pengukuran & Skala \\
\hline $\begin{array}{l}\text { Manajemen } \\
\text { Laba (Y) }\end{array}$ & $\begin{array}{l}\text { suatu upaya dalam } \\
\text { pelaporan kondisi } \\
\text { keuangan perusahaan } \\
\text { terutama laba yang } \\
\text { dihasilkan dalam } \\
\text { periode tertentu yang } \\
\text { dilakukan oleh } \\
\text { manajemen secara } \\
\text { sengaja untuk tujuan } \\
\text { tertentu dengan } \\
\text { kewenangan yang } \\
\text { dimilikinya } \\
\text { berdasarkan koridor } \\
\text { kebijakan/metode } \\
\text { akuntansi berterima } \\
\text { umum sehingga dapat } \\
\text { mempengaruhi opini } \\
\text { public maupun } \\
\text { investor }\end{array}$ & $\begin{array}{l}\text { Discretionery Accruals dengan } \\
\text { mengurangi total akrual denga akrual } \\
\text { non diskresioner } \\
\text { DACit = TACCit - NDAit }\end{array}$ & Rasio \\
\hline $\begin{array}{l}\text { Beban Pajak } \\
\text { Tangguhan } \\
\left(\mathrm{X}_{1}\right)\end{array}$ & $\begin{array}{l}\text { Jumlah pajak } \\
\text { penghasilan yang } \\
\text { terutang (payable) atau } \\
\text { terpulihkan } \\
\text { (recoverable) pada } \\
\text { tahun mendatang } \\
\text { sebagai akibat adanya } \\
\text { perbedaan temporer } \\
\text { yang boleh } \\
\text { dikurangkan dari sisa } \\
\text { kompensasi kerugian } \\
\text { yang dapat } \\
\text { dikompensasikan }\end{array}$ & $\begin{array}{l}\text { Nilai Beban Pajak Tangguhan yang } \\
\text { ada pada laporan keuangan laba rugi }\end{array}$ & Rasio \\
\hline Profitabilitas & $\begin{array}{l}\text { Kemampuan } \\
\text { perusahaan untuk } \\
\text { menghasilkan } \\
\text { keuntungan dan } \\
\text { mengukur tingkat } \\
\text { efisiensi operasional }\end{array}$ & ROA $=\frac{\text { Laba Bersih setelah pajak }}{\text { Total Asset }}$ & Rasio \\
\hline
\end{tabular}

Sumber : Data diolah 2018 


\section{Sosio e-kons}

Volume 10, No. 3, Desember 2018, pp. 270-278

e-ISSN: $2502-5449$

p-ISSN: 2085-2266

Pengumpulan data dalam penelitian ini meliputi: 1). Dokumentasi perusahaan industri minyak bumi di BEI, 2). Kajian pustaka.

Secara sistematik, bagan alir dalam penelitian ini dapat digambarkan sebagai berikut:

Gambar 3.1

\section{Bagan Alir Penelitian}

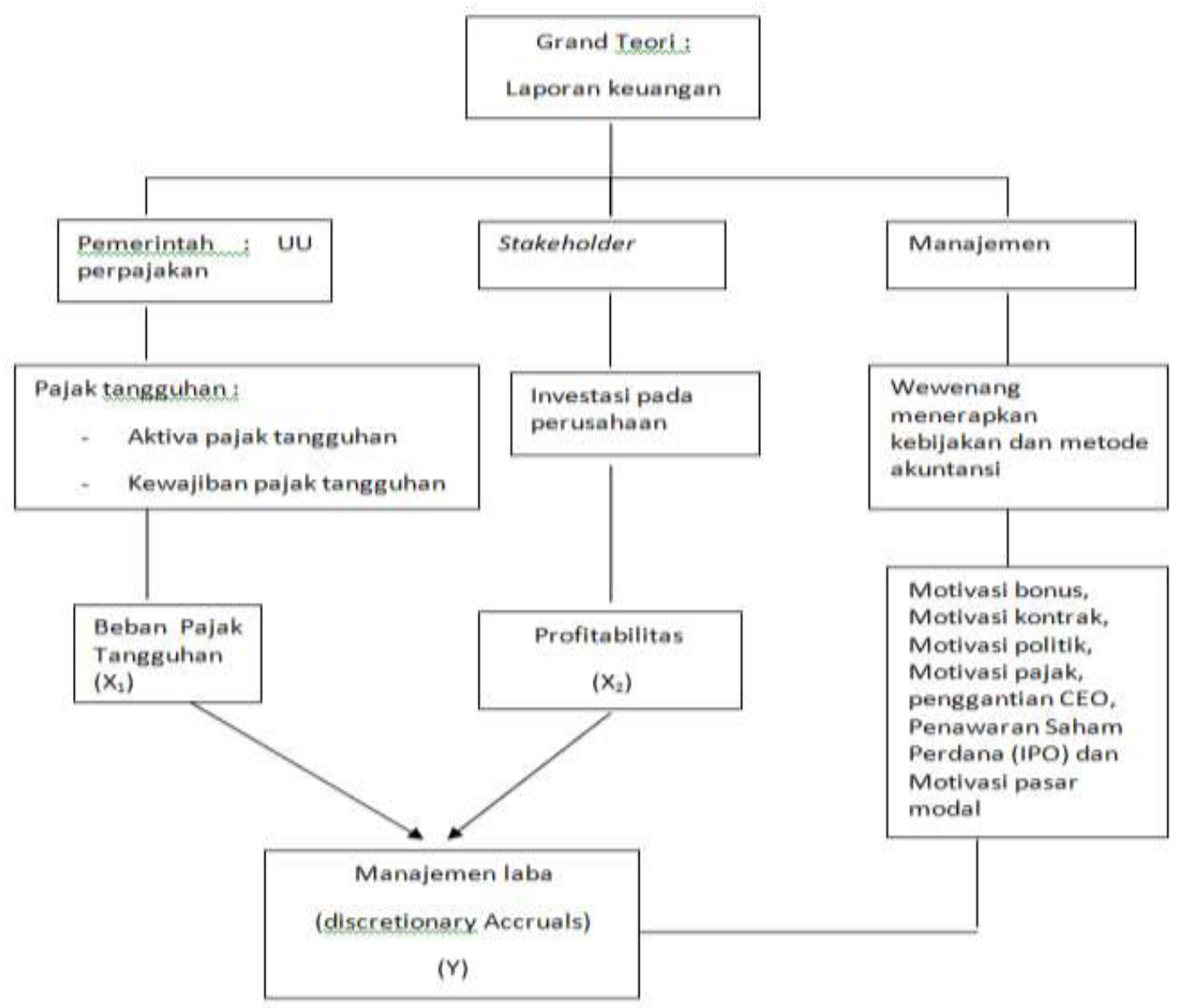

Data yang telah diperoleh diolah dan dianalis dengan menggunakan Regresi berganda (Sugiyono, $2013: 40$ ), dengan formulasi sebagai berikut:

$Y=a+\beta_{1} X_{1}+\beta_{2} X_{2}+e$

dimana:

Y : Variabel dependen (Manajemen Laba)

$\mathrm{X}_{1}$ : Variabel independen (Beban Pajak Tangguhan)

$\mathrm{X}_{2}$ : Variabel independen (Profitabilitas)

$\beta \quad:$ Koefisien Konstanta

$\varepsilon_{1}:$ Error term 


\section{Sosio e-kons}

Volume 10, No. 3, Desember 2018, pp. 270-278

e-ISSN: 2502-5449

p-ISSN: 2085-2266

HASIL DAN PEMBAHASAN

Perusahaan yang dijadikan sampel

Tabel 4.1

\section{Daftar Perusahaan}

\begin{tabular}{cll}
\hline No & Presentase & \multicolumn{1}{c}{ Nama Perusahaan } \\
\hline 1 & $97,9 \%$ & $\begin{array}{l}\text { Chevron Pasific } \\
\text { ndonesia }\end{array}$ \\
\hline 2 & $101,4 \%$ & Mobil Cepu Ltd \\
\hline 3 & $94,9 \%$ & Pertamina EP \\
\hline 4 & $96,3 \%$ & $\begin{array}{l}\text { Total E \& P } \\
\text { Indonesia }\end{array}$ \\
\hline 5 & $94,9 \%$ & $\begin{array}{l}\text { Pertamina Hulu } \\
\text { Energi ONWJ }\end{array}$ \\
\hline 6 & $101,2 \%$ & CNOOC SES Ltd \\
\hline 7 & $96,5 \%$ & Medco Natuna \\
\hline 8 & $101,8 \%$ & $\begin{array}{l}\text { Chevron Company } \\
\text { Indonesia }\end{array}$ \\
\hline 9 & $98,7 \%$ & $\begin{array}{l}\text { Petronas Carigali } \\
\text { Ketapang }\end{array}$ \\
\hline 10 & $104,8 \%$ & Vico \\
\hline
\end{tabular}

Sumber : Data BEI 2017

Berdasarkan tabel disamping dapat diketahui bahwa perusahaan minyak bumi yang menyumbangkan minyak bumi terbesar adalah Vico yaitu 104,8 \% dari yang ditargetkan.

\section{Uji Determinasi dan Korelasi}

Pada uji determinasi dilakukan untuk mengetahui besarnya paengaruh variabel terikat terhadap variabel bebas. Sedangkan uji korelasi dilakukan untuk mengetahui hubungan antara variabel terikat dengan variabel bebas. Pada pembahasan kali ini profitabilitas (X1) dan beban pajak tangguhan (X2) sebagai variabel terikat dan manajemen laba sebagai variabel (Y). Nilai koefisien determinasi $\left(\mathrm{R}^{2}\right)$ seperti tabel dibawah ini:

Tabel 4.1

Uji Determinasi $\left(\mathrm{R}^{2}\right)$

Model Summary ${ }^{\mathrm{b}}$

\begin{tabular}{|c|c|c|c|c|c|c|c|c|c|c|}
\hline \multirow[b]{2}{*}{ Model } & \multirow[b]{2}{*}{$\mathrm{R}$} & \multirow[b]{2}{*}{$\begin{array}{c}\mathrm{R} \\
\text { Square }\end{array}$} & \multirow[b]{2}{*}{$\begin{array}{c}\text { Adjusted } \\
\text { R } \\
\text { Square }\end{array}$} & \multirow[b]{2}{*}{$\begin{array}{l}\text { Std. Error } \\
\text { of the } \\
\text { Estimate }\end{array}$} & \multicolumn{5}{|c|}{ Change Statistics } & \multirow[b]{2}{*}{$\begin{array}{l}\text { Durbin- } \\
\text { Watson }\end{array}$} \\
\hline & & & & & $\begin{array}{c}\text { R } \\
\text { Square } \\
\text { Change }\end{array}$ & $\begin{array}{c}\mathrm{F} \\
\text { Change }\end{array}$ & 11 & df 2 & $\begin{array}{l}\text { Sig. F } \\
\text { Change }\end{array}$ & \\
\hline 1 & $.774^{\mathrm{a}}$ & .600 & .591 & 5.11185 & .600 & 72.632 & 2 & 97 & .000 & 1.796 \\
\hline
\end{tabular}


Model Summary ${ }^{\mathrm{b}}$

\begin{tabular}{|c|c|c|c|c|c|c|c|c|c|c|}
\hline \multirow[b]{2}{*}{ Model } & & \multirow[b]{2}{*}{$\begin{array}{c}\mathrm{R} \\
\text { Square }\end{array}$} & \multirow[b]{2}{*}{$\begin{array}{c}\text { Adjusted } \\
\text { R } \\
\text { Square }\end{array}$} & \multirow[b]{2}{*}{$\begin{array}{l}\text { Std. Error } \\
\text { of the } \\
\text { Estimate }\end{array}$} & \multicolumn{5}{|c|}{ Change Statistics } & \multirow[b]{2}{*}{$\begin{array}{l}\text { Durbin- } \\
\text { Watson }\end{array}$} \\
\hline & & & & & $\begin{array}{c}\mathrm{R} \\
\text { Square } \\
\text { Change }\end{array}$ & $\begin{array}{c}\mathrm{F} \\
\text { Change }\end{array}$ & df1 & df2 & $\begin{array}{l}\text { Sig. F } \\
\text { Change }\end{array}$ & \\
\hline 1 & $.774^{\mathrm{a}}$ & .600 & .591 & 5.11185 & .600 & 72.632 & 2 & 97 & .000 & 1.796 \\
\hline
\end{tabular}

a. Predictors: (Constant), Profitabilitas, Beban pajak tangguhan

b. Dependent Variable: Manajemen laba

Sumber : Data Diolah 2018

Dari tabel diatas nilai koefisien determinasi dari profitabilitas dan beban pajak tangguhan terhadap struktur modal yaitu sebesar 0.600. nilai tersebut menunjukkan bahwa sebesar 59,1\% variasi pada manajemen laba dipengaruhi oleh profitabilitas dan beban pajak tangguhan, sedangkan sisanya 48,9\% (100\% - 59,1\%) dipengaruhi variable lain diluar penelitian ini.

Uji korelasi dapat dilihat pada kolom $\mathrm{R}$, nilai $\mathrm{R}$ menunjukkan nilai korelasi yang terjadi antara variabel terikat dengan variabel bebas.

Pada tabel 4.1 diatas diperoleh angka korelasi antara profitabilitas dan beban pajak tangguhan terhadap manajemen laba sebesar 0.774 , artinya antara variabel profitabilitas dan beban pajak tangguhan dengan manajemen laba memiliki hubungan korelasi sedang dan searah. Searah artinya jika profitabilitas dan beban pajak tangguhan tinggi maka manajemen laba juga tinggi.

\section{Analisis Regresi Linier Berganda}

Analisis Pengaruh beban pajak tangguhan dan profitabilitas terhadap manajemen laba. Hasil analisis regresi berganda ditunjukkan pada tabel dibawah ini :

Tabel.4.2

Hasil Perhitungan Nilai Koefisien Persamaan Regresi Coefficients $^{\mathrm{a}}$

\begin{tabular}{|c|c|c|c|c|c|c|c|c|}
\hline \multirow[b]{2}{*}{ Mode } & & \multicolumn{2}{|c|}{$\begin{array}{l}\text { Unstandardized } \\
\text { Coefficients }\end{array}$} & \multirow{2}{*}{$\begin{array}{c}\text { Standardized } \\
\text { Coefficients } \\
\text { Beta }\end{array}$} & \multirow[b]{2}{*}{$\mathrm{T}$} & \multirow[b]{2}{*}{ Sig. } & \multicolumn{2}{|c|}{ Collinearity Statistics } \\
\hline & & B & $\begin{array}{l}\text { Std. } \\
\text { Error }\end{array}$ & & & & Tolerance & VIF \\
\hline \multirow[t]{3}{*}{1} & (Constant) & 11.164 & 5.535 & & 2.017 & .046 & & \\
\hline & $\begin{array}{l}\text { Bebanpajakt } \\
\text { angguhan }\end{array}$ & .629 & .059 & .700 & 10.616 & .000 & .948 & 1.055 \\
\hline & Profitabilitas & .151 & .048 & .207 & 3.140 & .002 & .948 & 1.055 \\
\hline
\end{tabular}

a. Dependent Variable: Manajemen laba (Sumber : Data diolah 2018)

Hasil persamaan regresi linier berganda sebagai berikut: $Y=11.164+0,629 \mathrm{X}_{1}+0,151 \mathrm{X}_{2}+\mathrm{e}$

Dari hasil persamaan regresi terlihat bahwa manajemen laba $(\mathrm{Y})$ dipengaruhi oleh variable beban pajak tangguhan $(0,629)$ dan profitabilitas $(0,151)$ berpengaruh positif terhadap manajemen laba perusahaan.

Dalam penelitian ini dapat digambarkan dengan hasil regresi linier dapat dikatakan bahwa pengaruh profitabilitas terhadap manajemen laba menunjukkan adanya pengaruh yang searah dan positif. Hal ini sejalan dengan penelitian sebelumnya yang menyatakan profitabilitas memiliki pengaruh terhadap manajemen laba. Sehingga hasil empirisnya sejalan dengan asumsi awal. Hal ini dibuktikan dengan nilai signifikansi sebesar 0,000 yang lebih kecil dari tingkat signifikansi sebesar 0,05 . Hal tersebut menjelaskan bahwa pada saat perusahaan mengalami 
profitabilitas maka peluang untuk melakukan praktik manajemen laba besar terkait dengan bonus manajer.

Hasil penelitian ini sejalan dengan penelitian terdahulu yang dilakukan oleh Dewi Utami (2015) dalam penelitiannya" Faktor-faktor yang Mempengaruhi Ketepatan Waktu Pelaporan Keuangan pada Perusahaan Sub Sektor Bank yang Terdaftar di Bursa Efek Indonesia "yang membuktikan bahwa hubungan antara variabel profitabilitas dengan manajemen laba adalah positif, dimana semakin tinggi profitabilitas maka semakin tinggi kemungkinan perusahaan melakukan manajemen laba.

Berdasarkan penelitian ini, didapat hasil bahwa beban pajak tangguhan berpengaruh positif terhadap manajemen laba. Beban pajak memiliki pengaruh positif terhadap manajemen laba, dibuktikan dengan nilai signifikan sebesar 0,002 yang lebih kecil dari tingkat signifikansi sebesar 0,05. Hasil empiris dalam penelitian ini sejalan dengan asumsi awal. Bahwa manajemen melakukan manajemen laba karena terdapat beberapa faktor antara lain adalah faktor menghemat dalam membayar pajak.

Berdasarkan hasil penelitian uji simultan variabel beban pajak tangguhan dan profitabilitas terhadap manajemen laba menunjukkan pengaruh yang kuat dan searah. Hal ini karena beban pajak tangguhan apabila digabungkan dengan profitabilitas dalam satu keadaan maka akan dapat membuktikan terjadinya manajemen laba, dengan probabilitas maka manajemen dapat mengetahui kemampuan perusahaan untuk mendapatkan laba pada masa mendatang sehingga memudahkan dalam menunda atau mempercepat laba maupun menunda pajak pada periode tertentu.

Hasil penelitian ini sejalan dengan penelitian terdahulu yang dilakukan oleh Assih, P.,dan Gudono.2012 dalam penelitiannya "Hubungan Tindakan Perataan Laba dengan Reaksi Pasar Atas Pengumuman Informasi Laba Perusahaan yang Terdaftar di Bursa Efek Jakarta" yang membuktikan bahwa adanya pelaksanaan manajemen laba dalam perusahaan. Perusahaan yang memiliki ROA yang lebih tinggi cenderung melakukan manajemen laba karena manajemen mangetahui kemampuan perusahaan untuk mendapatkan laba pada masa mendatang sehingga memudahkan dalam menunda atau mempercepat laba pada periode tertentu (Assih dan Gudono, 2012). Hal ini diperkuat dalam penelitian yang dilakukan oleh Igan Budiasih (2012) bahwa profitabilitas mempunyai pengaruh positif signifikan terhadap praktik perataan laba yang merupakan bagian dari praktik manajemen laba.

Besarnya pengaruh beban pajak tangguhan dan profitabilitas terhadap manajemen laba secara simultan dapat dilihat melalui koefisien determinan (KD). Dari hasil perhitungan, diperoleh Kd sebesar 59,1\% terhadap manajemen laba, sisanya 41,9\% dipengaruhi oleh faktor lain yang tidak diteliti dalam penelitian ini.Dalam melaksanakan manajemen laba pihak manajemen harus selalu memperhitungkan besarnya beban pajak tangguhan yang ada dan besarnya profit yang diharapkan dari perusahaan.

\section{SIMPULAN DAN SARAN}

Berdasarkan data dan pengolahan di atas dapat disimpulkan bahw ada pengaruh positif antara variabel bebas (beban pajak tangguhan dan profitabilitas) terhadap manajemen laba. Namun variabel beban pajak tangguhan memberikan pengaruh cukup besar yaitu berdasarkan hasil uji t. dengan nilai thitung $(10,616)$ dengan nilai sig. $(0,000)>t$ tabel $(1,96)$ paling besar dibanding dengan variabel lainnya.

Memperluas jenis perusahaan sebagai sampel yang terdaftar di BEI, tidak hanya pada perusahaan minyak tetapi jenis perusahaan yang terdaftar di BEI, sehingga menambah peluang kejadian dalam penelitian sampel. 


\section{Sosio e-kons}

Volume 10, No. 3, Desember 2018, pp. 270-278

e-ISSN: 2502-5449

p-ISSN: 2085-2266

http://journal.lppmunindra.ac.id/index.php/sosio_ekons

Penggunaan variabel beban pajak tangguhan dalam penelitian di Indonesia pada masa datang dapat menjadi alternatif yang baik, oleh karena itu perlu dilakukan penelitian mengenai komponen-komponen beban pajak tangguhan. Hal ini dilakukan untuk meningkatkan kemampuan beban pajak tangguhan dalam memprediksi adanya upaya manajemen laba yang dilakukan oleh perusahaan-perusahaan di Indonesia.

\section{DAFTAR RUJUKAN}

Assih, P.G. (2012). Hubungan Tindakan PerataanLaba dengan Reaksi PasarAtas Pengumuman Informasi Laba Perusahaan yang Terdaftar di Bursa Efek Jakarta.Jurnal Riset Akuntansi Indonesia : 35-53.

Budiasih, I. (2012). Faktor-Faktor yang Mempengaruhi Praktik Perataan Laba.Media AUDIJurnal Akuntansi dan Bisnis, Vol. 4.Januari : 1-14.

Gumanti, T, A. (2011). Earnings Management:Suatu Telaah Pustaka. Jurnal Akuntansi \& Keuangan, 2 (2) : 104- 115.

Kasmir. (2011). Analisis Laporan Keuangan. Raja Grafindo Persada :Jakarta

Lukman, S. (2013). Manajemen Keuangan Perusahaan. PT. Raja Grafindo, Jakarta

Sekaran, U. (2014). Metodologi Penelitian untuk Bisnis (Research Method for Business) Buku 1 Edisi 4. Jakarta: Salemba Empat

Scott R.W. (2012). Financial Accounting Theory, 2nd edition. Prentice Hall Canada Inc, Scarborough, Ontario.

Susan, I. (2012). Manajemen Keuangan. Pustaka: Bandung

Utami, D. (2015). Faktor-faktoryang Mempengaruhi Ketepatan Waktu Pelaporan Keuangan pada Perusahaan Sub Sektor Bank yang Terdaftar di Bursa Efek Indonesia. Skripsi. Universitas PGRI Yogyakarta.

Wild, John J., Subramanyam, K. R. \& Halsey, Robert F. (2013). Analisis Laporan Keuangan, edisi 8 Buku 2 Penerjemah: Bachtiar dan Harahap. Salemba Empat: Jakarta

Zain, M. (2013). Manajemen Perpajakan. Salemba Empat: Jakarta. 